\title{
KELAYAKAN FINANCIAL DAN EKONOMI USAHA PEMBUATAN PAKAN TERNAK LIMBAH AMPAS SAGU (Metroxylon Sago)
}

\author{
Haedar $^{1}$, Muhammad Kasran ${ }^{2}$ \\ Sekolah Tinggi Ilmu Ekonomi Muhammadiyah Palopo

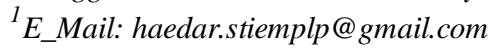

\begin{abstract}
Abstrak: Penelitian ini bertujuan untuk mengidentifikasi biaya baik secara finansial maupun secara ekonomi dan penentuan manfaat finansial dan manfaat ekonomi terhadap kelayakan produksi Limbah Ampas Sagu dalam upaya pemanfaatannya menjadi produk pakan ternak bernilai ekonomis dan komersial. Ketersediaan ampas sagu yang melimpah dihasilkan dari proses pengolahan sagu (Metroxylon sagu) merupakan masalah bagi masyarakat pedesaan karena mencemari lingkungan dan menjadi limbah yang tidak berguna. Pemanfaatan limbah sagu dalam skala besar masih jarang dilakukan di Indonesia. Salah satu alternative lain dalam memanfaatkan limbah ampas sagu adalah mengkonversi menjadi bahan baku utama pembuatan pakan ternak. Hal ini memungkinkan menjadi solusi untuk memutus rantai kemiskinan dari meluasnya tingkat kemiskinan di pedesaan serta rendahnya tingkat produksi dan pendapatan masyarakat. Salah satu kendala yang dihadapi oleh usaha peternakan adalah belum tercukupinya kebutuhan nutrisi ternak dan mahalnya harga pakan jadi dipasaran, sehingga masih dibutuhkan upaya dalam menanggulangi dengan menggali sumber pakan alternative yang terjangkau dan dan melimpah jumlahnya. Data yang akan digunakan meliputi data primer dan sekunder. Metode analisis yang digunakan dalam penelitian ini untuk penentuan manfaat finansial dan manfaat ekonomi, penentuan biaya finansial dan biaya ekonomi, meng gunakan metode penentuan harga bayangan, metode perkiraan Opportunity Cost of Capital (OOC), analisis kelayakan Investasi dan analisis sensitivitas. Hasil analisis kelayakan finansial maka usaha pembuatan pakan ternak berbahan dasar limbah ampas sagu layak untuk dilaksanakan. Hasil analisis sensitivitas dengan skenario menunjukkan bahwa pada usaha pembuatan pakan ternak ini akan tidak layak dilaksanakan pada kondisi jika terjadi penurunan jumlah output (limbah apas sagu) sebesar 10 persen disertai dengan penurunan captive market sebesar 10 persen, biaya tetap (tenaga kerja ahli dan operasional) sebesar 20 persen. Analisis Switching Value menunjukkan usaha ini akan tidak layak pada penurunan potensi limbah ampas sagu lebih dari 18,428 persen dan penurunan captive market sebesar 12 persen
\end{abstract}

Kata kunci: Ampas Sagu, Analisis Kelayakan Finansial, Kelayakan Ekonomi, Pakan Ternak

\section{PENDAHULUAN}

Ukuran keberhasilan pertanian berorientasi pada peningkatan produksi, dan bukan pada terjadinya perubahan struktur yang dapat memberdayakan masyarakat pedesaan, sehingga terjadi pembiasan yang diakibatkan main stream yang terlalu berorientasi pada peningkatan pertumbuhan ekonomi, sehingga mengakibatkan orientasi dititik beratkan pada sector industri.

Salah satu kendala yang dihadapi oleh usaha peternakan adalah belum tercukupinya kebutuhan nutrisi terutama protein pakan, sehingga ternak belum dapat tumbuh dan berkembang dengan baik. Pakan di daerah tropis kebanyakan bermutu rendah dengan serat kasar yang tinggi. Keadaan ini merupakan tantangan bagi sub sektor peternakan, karena perlu mencari pakan alternatif untuk meningkatkan produksi ternak. Usaha pertanian khususnya pada sub sektor peternakan dituntut lebih modern dan professional dengan memanfaatkan inovasi teknologi yang menekankan aspek efisiensi usaha termasuk pada bahan dan teknologi pakan. Pengembangan usaha ternak harus didukung dengan pengembangan industri pakan melalui optimalisasi pemanfaatan sumber-sumber bahan baku lokal spesifik lokasi dan berorientasi pada pola integrasi tanamanternak. 
Potensi bahan baku lokal berupa limbah pertanian, perkebunan dan agroindustri sangat besar, namun hanya sebagian kecil yang digunakan sebagai pakan. Ampas sagu (Metroxylon sago) merupakan sisa proses pengolahan sari pati sagu yang merupakan empulur. Prastowo (2007); Kiston et al., (2011) Hamparan sagu liar di Indonesia memiliki luas 1,5 juta hektar dari luasan tersebut pada tahun 2005 dapat diproduksi sagu sebanyak 15 juta ton karena setiap batang sagu menghasilkan $200 \mathrm{~kg}$ sagu. Luas areal tanaman sagu di Indonesia mencapai 1,2 juta ha dengan produksi berkisar 8,4-13,6 juta ton per tahun (Balika Litbang, 2013). Limbah pengolahan sagu yang didapatkan pada proses pengolahan tepung sagu dengan perbandingan 1:6 (Rumalatu, 1981). Berdasarkan proporsi tersebut jumlah limbah sagu sebanyak +245.000 ton/hari. Jumlah limbah yang banyak tersebut, sampai saat ini belum dimanfaatkan sebagaimana mestinya hanya dibiarkan menumpuk pada tempat - tempat pengolahan tepung sagu sehingga menyebabkan pencemaran lingkungan. Kalaupun ada ternak yang memanfaatkannya, hanya ternak-ternak yang berada di sekitar lokasi pengolahan tepung sagu, yang langsung mengkonsumsi di tempat penumpukan ampas tanpa dikontrol. Proses pengolahannya meliputi pemotongan untuk merubah ukuran partikel, pengeringan, penggilingan/penghancuran, pencampuran antara bahan serat dan konsentrat yang berupa padatan maupun cairan, serta pengemasan.

Pemanfaatan sumber daya lokal secara optimal merupakan langkah strategis dalam upaya mencapai efisiensi usaha produksi ternak unggas di Indonesia. Hal ini akan semakin nyata, apabila sumber daya tersebut bukan merupakan kebutuhan langsung bagi kompetitor, seperti manusia atau jenis ternak lain. Oleh karena pakan sangat erat kaitannya dengan produktivitas dan biaya produksi, maka pemanfaatan bahan baku lokal secara efisien akan berpengaruh nyata terhadap perkembangan ternak.

Sektor pertanian masih memiliki potensi untuk ditingkatkan apabila berhasil menangani kendala-kendala yang meliputi: produktivitas, efisiensi usaha, konversi lahan pertanian, keterbatasan sarana dan prasarana pertanian, serta terbatasnya kredit dan infrastruktur pertanian. Secara khusus sarana dan prasarana sub sector peternakan di wilayah timur Indonesia masih sangat kurang sehingga sumber daya peternakan di wilayah ini dengan potensi yang cukup besar belum dimanfaatkan secara optimal.

Dari uraian diatas menunjukkan hingga saat ini masyarakat pedesaan termasuk didalamnya peternak yang sebagian besar di pedesaan masih berada dalam kondisi kurang sejahtera ditinjau dari aspek ekonomi, sosial, politik dan budaya. Penelitian ini akan menyikapi kondisi dan peluang yang ada di tengah masyarakat untuk memberikan solusi dalam meningkatkan potensi sumberdaya local dan nilai ekonomi limbah agrobisnis yang berlimpah dan belum termanfaatkan, meskipun kebijakan kebijakan pembangunan yang berorientasi ke pedesaan sejak lama telah di implementasikan oleh pemerintah. Penelitian ini bertujuan menganalisis tingkat kelayakan dan menganalisis kepekaan proyek Usaha pembuatan Pakan Ternak dalam mengelola limbah Ampas Sagu di lokasi penelitian layak untuk dilaksanakan. 
Biaya dan manfaat perlu diidentifikasikan untuk melakukan penilaian terhadap rencana usaha pembuatan pakan ternak. Cara paling praktis adalah dengan membandingkan perbedaan barang dan jasa secara langsung dan menyatakan dalam satuan uang. Rangkaian dasar dalam perencanaan pelaksanaan usaha adalah siklus usaha. Siklus usaha terdiri dari tahap-tahap identifikasi, persiapan dan analisis penilaian, pelaksanaan dan evaluasi (Gittinger, 1986). Evaluasi adalah alat yang paling penting dalam suatu usaha yang sedang berjalan dan dapat dilakukan dalam beberapa kali selama pelaksanaan proyek tersebut. Penilaian terhadap suatu usaha atau proyek pada dasarnya untuk mengetahui apakah proyek tersebut layak dilaksanakan atau dipertahankan kelangsungan hidupnya.

Penilaian secara finansial adalah membandingkan biaya dan manfaat usaha berdasarkan kompensasi yang diberikan kepada perusahaan. Aktivitas yang memberikan nilai kepada perusahaan disebut sebagai manfaat. Biaya merupakan aktivitas yang mengurangi nilai perusahaan. Secara finansial penentuan biaya dan manfaat usaha berdasarkan harga pasar. Penilaian secara ekonomi berpatokan pada masyarakat secara keseluruhan. Analisis ekonomi menggunakan shadow price untuk menilai biaya dan manfaat (Gray, 2002)

\section{KAJIAN LITERATUR DAN PENGEMBANGAN HIPOTESIS}

Tanaman sagu (Metroxylon Sp.) merupakan salah satu tanaman penghasil karbohidrat yang cukup potensial di Indonesia yang tersebar di daerah pesisir dan pulau-pulau besar maupun kecil, dari Sabang sampai Merauke. Ampas sagu merupakan hasil samping dari pengolahan sagu yang terdiri dari serat-serat empulur yang diperoleh dari hasil pemarutan / pemerasan isi batang sagu. Ampas yang dihasilkan dari proses ektraksi ini sekitar 14\% dari total berat basah batang sagu (Flach, 1997). Limbah ampas sagu pada umumnya belum dimanfaatkan, yang pada akhirnya akan mencemari lingkungan. Limbah dari hasil pengolahan sagu, dibuang langsung ke sungai dan menjadi sumber polutan. Keasaman tanah tempat pembuangan dapat mencapai $\mathrm{pH} 4$ atau lebih rendah (Kompiang, 1995). Mirnawati dan Ciptaan (1999) menyatakan bahwa berdasarkan hasil analisis proksimat, empulur sagu mengandung protein kasar 2,95\%, lemak kasar $1,44 \%$, serat kasar $16,47 \%$, kalsium $0,19 \%$, fosfor $0,05 \%$, kadar air 12,88- 17,88\%, abu 0,05-0,28\%, dan energi metabolisme (EM) sebesar 2.900 $\mathrm{kcal} / \mathrm{kg}$; Kandungan zat nutrisi yang terdapat pada limbah sagu yaitu: protein kasar sebesar 3,36\%; NDF 87,40\%; ADF 42,11 dan energy kasar 4.148 kka1/kg (Nurkurnia, 1989; Trisnowati, 1991), relatif sebanding dengan zat nutrisi pakan rumput.

Harry Tum dan Batsebat Wiro (1999) telah memberikan ampas sagu terhadap ayam buras selama 8 (delapan) minggu di Desa Koya Barat, Kotamadya Jayapura. Pada pengkajian ini pertambahan bobot badan ayam buras tertinggi sebesar 100 gr/minggu berada dibawah rata-rata hasil pengkajian terdahulu (120 gr/minggu $)$ dengan tambahan 20\% sagu (Uhi et al., 1997).

Kiston et al., (2011) Limbah pengolahan sagu termasuk kategori limbah basah (wet byproducts) karena masih mengandung kadar air 70 - $80 \%$, sehingga dapat rusak dengan cepat apabila 
tidak segera diproses. Perlakuan melalui pengeringan membutuhkan biaya yang relatif tinggi sehingga perlu dikembangkan melalui teknologi alternatif lain agar produk tersebut dapat dimanfaatkan secara lebih efisien. Teknologi silase adalah suatu proses fermentasi mikroba merubah pakan menjadi meningkat kandungan nutrisinya (protein dan energi) dan disukai ternak karena rasanya relatif manis. Silase merupakan proses mempertahankan kesegaran bahan pakan dengan kandungan bahan kering $30-35 \%$ dan proses ensilase ini biasanya dalam silo atau dalam lobang tanah, atau wadah lain yang prinsipnya harus pada kondisi anaerob (hampa udara), agar mikroba anaerob dapat melakukan reaksi fermentasi (Sapienza dan Bolsen, 1993).

\section{METODE DAN BAHAN}

Keberhasilan pembuatan silase berarti memaksimalkan kandungan nutrien yang dapat diawetkan. Selain bahan kering, kandungan gula bahan juga merupakan faktor penting bagi perkembangan bakteri pembentuk asam laktat selama proses fermentasi (Khan et al., 2004) Pada fase awal proses ensilase, enzim yang bekerja dalam proses respirasi pada bahan mengoksidasi karbohidrat yang terlarut, menghasilkan panas dan menggunakan gulagula yang seyogyanya siap pakai untuk proses fermentasi. Kehilangan gula pada proses respirasi merupakan hal yang menyulitkan baik dari sudut pandang pengawetan melalui proses pembuatan silase maupun dari segi nilai nutrisinya. Gula merupakan substrat bagi bakteri penghasil asam laktat yang akan menghasilkan asam yang berfungsi sebagai pengawet bahan yang disilase tersebut.
Tahap awal pembuatan silase adalah melakukan pencacahan ampas sagu dengan menggunakan mesin pencacah, kemudian melakukan pengurangan kadar air ampas sagu (menggunakan panas matahari) selama $\pm 6-8$ jam tergantung intensitas sinar matahari sehingga kadar air limbah sagu tersebut berkisar 50 - 55\%, kemudian diproses menjadi silase melalui cara dicampur dengan bahan aditif yaitu molases/ gula tetes $15 \%$ untuk merangsang aktivitas mikroba dalam proses fermentasi pembuatan silase, serta untuk meningkatkan kandungan energi dan protein silase yang dihasilkan nantinya. Setelah dicampur merata dimasukkan ke dalam kantong (dua lapis) dengan ukuran $50 \mathrm{~kg}$, dipadatkan untuk meminimumkan udara (proses fermentasi anaerob). Kemudian disimpan ditempat teduh (bebas sinar matahari) selama \pm 3 minggu tergantung cepat lambatnya proses silase.

Ampas sagu yang telah mengalami fermentasi sempurna memiliki ciri-ciri sebagai berikut: aroma khas/aroma buah atau beraroma seperti tape ketan, warna agak kemerahan, teksturnya lembut dan rasanya agak manis. Hasil fermentasi dijemur sampai kering dan siap digunakan dalam ransum.

Aspek-Aspek dalam Penelitian

\section{Aspek Teknis}

Aspek teknis merupakan suatu aspek yang berkenaan dengan proses pembangunan proyek secara teknis dan pengoperasiannya setelah proyek tersebut selesai dibangun. Berdasarkan analisis ini dapat diketahui rancangan awal penaksiran biaya investasi termasuk biaya eksploitasi (Husnan dan Suwarsono, 2000) 
Analisis ini lebih jauh menyelidiki tentang lokasi tempat proyek, apakah terdapat persediaan air, listrik, prasarana jalan raya. Aspek teknis juga membahas mengenai persediaan bahan-bahan mentah yang diperlukan untuk proyek apakah mencukupi atau tidak, dan apakah barang-barang tersebut (sebagian atau seluruhnya) harus di datangkan dari tempat lain atau di impor. Secara teknis dari sisi hasil produksi, analisis ini membahas mengenai ketersediaan fasilitas penyimpanan dan pengiriman hasil produksi.

\section{Aspek Institusional-Manaje rial}

Aspek ini berhubungan dengan penetapan institusi atau lembaga proyek yang harus mempertimbangkan pekerjaan-pekerjaan apa yang diperlukan untuk menjalankan operasi proyek tersebut. Persyaratan-persyaratan yang diperlukan untuk bisa menjalankan pekerjaan-pekerjaan tersebut dan juga struktur organisasi yang akan dipergunakan dalam suatu proyek.

\section{Aspek Sosial}

Aspek sosial mempertimbangkan pola dan kebiasaan-kebiasaan sosial yang lebih luas dari investasi yang diusulkan. Proyek harus tanggap pada keadaan sosial dan dampak lingkungan yang merugikan. Pertimbangan mengenai aspek sosial dalam analisis proyek penting untuk kelangsungan proyek, sebab tidak ada proyek yang akan bertahan lama bila tidak bersahabat dengan lingkungan (Gittinger, 1986).

\section{Aspek Pasar}

Aspek pasar perlu dilakukan melihat dari banyaknya perusahaan baru yang muncul dan adanya kemungkinan memiliki jenis usaha yang sama. Aspek pasar menjadi mutlak untuk dianalisis agar tidak melakukan kegagalan dalam menjalankan usaha. Menurut Kadariah et.al, (1999), aspek komersial menyangkut penawaran input (barang dan jasa) yang diperlukan proyek, baik waktu membangun proyek maupun pada waktu proyek sudah berproduksi, dan menganalisis pemasaran output yang akan diproduksi oleh proyek. Para pemasar menggunakan sejumlah alat untuk mendapatkan tanggapan yang diinginkan dari pasar sasaran mereka.

\section{Aspek Finansial}

Aspek finansial berhubungan dengan pengaruh-pengaruh finansial dari suatu proyek yang diusulkan terhadap para anggota yang tergabung di dalam proyek. Aspek ini membandingkan antara pengeluaran dan penerimaan suatu proyek.

\section{Analisis Finansial}

Dalam analisis finansial yang di perhatikan ialah hasil untuk modal saham (equity capital) yang ditanam dalam proyek, ialah hasil yang harus diterima oleh petani, pengusaha (businessmen), perusahaan swasta, suatu badan pemerintah, atau siapa saja yang berkepentingan dalam pembangunan proyek. Hasil finansial sering juga disebut "private return". Analisis finansial ini penting artinya dalam memperhitungkan insentif bagi orang-orang yang turut serta dalam mensukseskan pelaksanaan proyek. Sebab, tidak ada gunanya untuk melaksanakan proyek yang menguntungkan dilihat dari sudut perekonomian sebagian keseluruhan, jika para petani yang menjalankan aktifitas produksi tidak bertambah baik keadaannya.

Perbedaan yang mendasar dalam analisis finansial dengan analisis ekonomi terdapat di beberapa komponen, yaitu harga, pajak, subsidi 
dan bunga. Analisis finansial menggunakan harga pasar untuk unsur-unsur biaya maupun hasil. Analisis ekonomi menggunakan harga bayangan atau shadow price, ialah harga yang menggambarkan nilai sosial atau nilai ekonomi yang sesungguhnya bagi unsur-unsur biaya maupun hasil. Perhitungan bunga berdasarkan analisis finansial dibedakan sebagai berikut:

1. Bunga yang dibayar kepada kreditur dianggap sebagai biaya, sedang pembayaran kembali hutang dari luar proyek dikurangkan dari hasil bruto sebelum didapatkan arus manfaat.

2. Bunga atas modal proyek (input or paid to entity) tidak dianggap sebagai biaya, karena merupakan bagian dari "finansial return" yang diterima oleh modal proyek.

\section{Kriteria Keputusan Investasi}

Keputusan suatu investasi berjalan atau tidak, menggunakan pertimbangan "Kriteria Keputusan Investasi”. Kriteria keputusan investasi terdiri dari berbagai metode-metode yang telah menghitung manfaat suatu proyek berdasarkan perkiraan arus manfaat biaya (benefit-cost flow) perusahaan yang telah didiskontokan selama umur proyek. Kriteria-kriteria tersebut adalah: Net Present Value (NPV), Internal Rate of Return (IRR), Net Benefit and Cost Rasio (Net B/C) dan Payback Period atau masa pengembalian investasi (MPI). Setiap kriteria dipakai untuk menentukan diterima tidaknya suatu proyek atau dipakai untuk memberikan urutan berbagai usul investasi menurut keuntungan masing-masing.

\section{Analisis Kepekaan (Sensitivitas)}

Salah satu keuntungan dari analisis proyek yang dilakukan secara cermat adalah dapat diketahui kapasitas hasil proyek bila ternyata terjadi hal-hal di luar perencanaan. Oleh karena itu perlu dilakukan analisis sensitivitas, yaitu meneliti kembali suatu analisis untuk dapat melihat pengaruh-pengaruh yang akan terjadi akibat keadaan yang berubah-ubah (Gittinger, 1986). Hal ini bertujuan untuk melihat apa yang akan terjadi dengan hasil analisis proyek jika ada sesuatu kesalahan atau perubahan dalam dasar-dasar perhitungan biaya atau benefit (Kadariah, 1987)

Data dan informasi yang telah dikumpulkan, diolah dengan menggunakan program Microsoft Excel. Data dan informasi dikelompokkan terlebih dahulu ke dalam komponen arus biaya dan manfaat, dan disajikan dalam bentuk tabulasi yang digunakan untuk mengklasifikasi data yang ada serta untuk mempermudah proses analisis data.

Analisis data dalam penelitian ini dilakukan secara kualitatif dan kuantitatif. Analisis kualitatif dilakukan untuk mengetahui gambaran mengenai pelaksanaan pengolahan limbah ampas sagu. Analisis kuantitatif digunakan untuk menganalisis kelayakan finansial pembuatan pakan ternak yang diolah dengan menggunakan Software Microsoft Excel.

Aspek teknis pada penelitian ini berdasarkan pada hal-hal yang bersifat teknis. Penjelasan tersebut meliputi: penjelasan mengenai pembuatan pakan ternak dan fasilitas pendukung; konsep teknologi; kebutuhan bahan baku; bahan pencampur; tenaga kerja; rencana produksi dan rencana penjualan.

Secara teknis proyek dapat dilaksanakan apabila kebutuhan-kebutuhan proyek dapat terpenuhi, baik kebutuhan akan bahan-bahan maupun kebutuhan akan fasilitas-fasilitas dan teknologi. Hasil penelitian terhadap aspek teknis 
akan menentukan nilai-nilai yang terdapat dalam aspek finansial, sehingga menentukan layaktidaknya proyek secara finansial.

Analisis finansial mengolah data menggunakan kriteria kelayakan finansial yaitu NPV, IRR, Net B/C dan Payback Period. Pengolahan data tersebut dilakukan berdasarkan pada kerangka pemikiran yang telah disusun. Selain itu, dilakukan pula analisis Sensitivitas (kepekaan) untuk melihat kepekaan usaha pembangunan usaha pakan ternak dalam menghadapi kemungkinan terjadinya perubahan.

Rumus yang digunakan dalam perhitungan NPV adalah sebagai berikut:

$$
N P V=\sum_{i=0}^{n} \frac{B_{t}-C_{t}}{(1+i)^{n}}
$$

Dimana :

$\mathrm{B}_{\mathrm{t}}=$ Penerimaan yang diperoleh pada tahun ke-t

$\mathrm{C}_{\mathrm{t}}=$ Biaya yang dikeluarkan pada tahun ke- $\mathrm{t}$

$\mathrm{n}=$ Umur ekonomis proyek

$\mathrm{i} \quad=$ Tingkat suku bunga $(\%)$

$\mathrm{t}=$ Tingkat investasi $(\mathrm{t}=0,1,2, \ldots, \mathrm{n})$

Dalam metode NPV terdapat tiga kriteria kelayakan investasi, yaitu:

1. NPV $>0$, berarti secara finansial usaha layak dilaksanakan karena manfaat yang diperoleh lebih besar dari biaya.

2. $\mathrm{NPV}=0$, berarti secara finansial usaha sulit dilaksanakan karena manfaat yang diperoleh hanya cukup untuk menutupi biaya yang dikeluarkan.

$\mathrm{NPV}<0$, berarti secara finansial usaha tidak layak dilaksanakan karena manfaat yang diperoleh lebih kecil dari biaya yang dikeluarkan.

\section{Net Benefit Ratio (NBCR)}

Net B/C ratio merupakan angka
perbandingan antara nilai kini arus
manfaat dibagi dengan nilai sekarang arus biaya. Angka tersebut menunjukkan tingkat besarnya tambahan manfaat pada setiap tambahan biaya sebesar satu satuan uang. Kriteria yang digunakan untuk pemilihan ukuran $\mathrm{Net} \mathrm{B} / \mathrm{C}$ ratio dari manfaat proyek adalah memilih semua proyek yang nilai Net B/C rationya sebesar satu atau lebih jika manfaat di diskontokan pada tingkat biaya opportunities capital (Gittinger, 1986), tetapi jika nilai Net $\mathrm{B} / \mathrm{C}<1$, maka proyek tersebut tidak layak untuk dilaksanakan. Rumus yang digunakan adalah sebagai berikut:

$$
N e t B / C=\frac{\sum_{i=1}^{n} B_{t}-C_{t}^{>0}}{\sum_{i=1}^{n} B_{t}-C_{t}{ }^{0}}
$$

Keterangan :

$\mathrm{Bt}=$ Penerimaan yang diperoleh pada tahun ke-t

$\mathrm{Ct}=$ Biaya yang dikeluarkan tahun ke- $\mathrm{t}$

$\mathrm{i}=$ Tingkat bunga (diskonto)

$\mathrm{t}=$ Tingkat investasi $(\mathrm{t}=0,1,2, \ldots . \mathrm{n})$

$\mathrm{n}=$ Umur ekonomis proyek

\section{Paybac Period}

Payback period merupakan jangka waktu periode yang dibutuhkan untuk membayar kembali semua biaya-biaya yang telah dikeluarkan di dalam investasi suatu proyek. Semakin cepat waktu pengambilan, semakin baik proyek tersebut untuk diusahakan. Akan tetapi analisis payback period memiliki kelemahan karena mengabaikan nilai uang terhadap waktu (present value) dan tidak memperhitungkan periode setelah payback period. Secara sistematis dapat dirumuskan sebagai berikut : 
$P=\frac{I}{A}$

Dimana :

$\mathrm{P}=$ Jumlah waktu yang diperlukan untuk mengembalikan modal

$I=$ Biaya investasi

$\mathrm{A}=$ Benefit bersih tiap tahun (rata-rata keuntungan)

\section{Analisis Kepekaan (Sensitivitas)}

\section{Analisis Sensitivitas dengan scenario}

Analisis dengan cara menghitung kembali ukuran kemanfaatan proyek dengan menggunakan estimasi baru dari satu atau lebih komponen biaya atau manfaat. Makin tinggi hasil yang diperkirakan, makin sensitif proyek yang diamati. Analisis sensitivitas dilakukan dengan cara mengkombinasi komponen komponen yang berubah untuk dapat mengestimasi pengaruh perubahan yang terjadi terhadap asumsi-asumsi yang digunakan dalam mengukur kemanfaatan

Analisis sensitivitas pada proyek usaha pakan ternak ini menggunakan sepuluh skenario dengan empat variabel. Dasar penentuan skenario tersebut adalah kondisi-kondisi yang berhubungan dilapangan.

\section{Nilai Pengganti (Switching Value)}

Suatu variasi dari analisis sensitivitas adalah nilai pengganti (switching value). Menurut Gittinger (1986), pengujian ini dilakukan sampai dicapai tingkat minimum dimana proyek dapat dilakukan dengan menentukan berapa besarnya proporsi manfaat yang akan turun akibat manfaat bersih sekarang menjadi nol $(\mathrm{NPV}=0)$. NPV sama dengan nol akan membuat IRR sama dengan tingkat suku bunga dan Net B/C sama dengan satu.
Analisis dilakukan pada perubahan harga input dan output yang terdiri dari empat perubahan, yaitu:

- Penurunan jumlah output

- Penurunan captive market

- Kenaikan biaya tetap (tenaga kerja ahli dan operasional)

- Kenaikan biaya variabel (tenaga kerja pelaksana, packging)

Pada proyek pembuatan Usaha Pakan Ternak Palopo menggunakan modal sendiri. Harga yang digunakan adalah harga pada waktu penelitian, yaitu pada bulan Mei 2016 sampai dengan bulan Juli 2016.

\section{HASIL DAN PEMBAHASAN}

\section{Proyeksi Aliran Kas}

Aliran kas dalam proyek usaha pembuatan pakan ternak terdiri dari aliran kas masuk dan aliran kas keluar. Aliran kas masuk (inflow) berasal dari penerimaan penjualan pakan ternak dan limbah serat sisa ayakan (pupuk organik) yang diusahakan. Arus kas keluar (outflow) berasal dari pengeluaran biaya investasi dan biaya operasional. Selisih antara arus kas masuk dengan arus kas keluar merupakan suatu keuntungan atau kerugian dari proyek usaha pembuatan pakan ternak.

\section{Arus Penerimaan (Inflow)}

Manfaat atau penerimaan proyek usaha pembuatan pakan ternak bersumber dari penjualan produk pakan ternak dan limbah sisa (pupuk organik) yang dihasilkan. Besarnya penerimaan sangat bergantung oleh banyaknya kapasitas produksi pakan ternak yang dihasilkan. Produk Pakan ternak yang dihasilkan dipasarkan untuk memenuhi kebutuhan pakan bagi peternak yang ada disekitar lokasi proyek dan pasar di Luwu 
Raya (Kota Palopo, Kab. Luwu, Kab. Luwu Utara, Kab. Luwu Timur, dan Kab. Luwu) maka untuk mendapatkan harga jual produk pakan ternak unggas dalam bentuk petet didasarkan pada harga pakan alternative yang berada di pasaran yaitu $\mathrm{Rp}$ 868,3 per $\mathrm{kg}$. Arus penerimaan selengkapnya dapat dilihat pada lampiran 1. Dengan demikian dapat diketahui penerimaan selama setahun yaitu sebesar Rp 182.343.000

Biaya tetap yang dikeluarkan pada proyek instalasi Pembuatan Pakan Ternak terdiri dari biaya gaji tetap pekerja ahli dan operasional, perawatan, dan PBB. Pengeluaran untuk gaji tenaga kerja ahli satu orang per tahun sebesar Rp 24.000.000, untuk gaji tenaga kerja operasional dua orang per tahun sebesar Rp 24.000.000. Biaya perawatan untuk mesin dan peralatan yang dikeluarkan per tahun sebesar Rp 120.000.000 dan untuk PBB per tahun sebesar Rp 2.000.000

Biaya tenaga kerja pelaksana Rp 250/kg digunakan untuk proses limbah hingga menjadi pupuk organik siap jual, target per bulan $465 \mathrm{~kg}$ pupuk organik biaya yang dikeluarkan per tahun sebesar Rp 1.395.000 Pupuk organik yang siap jual dikemas dengan kemasan $25 \mathrm{~kg}$, biaya yang dikeluarkan untuk packaging pertahun sebesar Rp 2.678.400 Untuk biaya pemasaran dibebankan sebesar Rp 25/kg dari total pupuk organik yang siap jual, dengan target penjualan perbulan sebesar $465 \mathrm{~kg}$, biaya yang dikeluarkan untuk pemasaran per tahun sebesar Rp 1.395.000.

\section{Hasil Analisis Kelayakan Finansial Instalasi Pembuatan Pakan Ternak dengan Diskon Faktor $9 \%$}

Berdasarkan perhitungan analisis kelayakan instalasi Pembuatan Pakan Ternak dengan populasi pohon sagu 500.000 batang, dengan tingkat diskonto sembilan persen nilai NPV yang dihasilkan dari proyek pembuatan pakan adalah sebesar $\mathrm{Rp}$ 1.140.146.594 dalam asumsi bahan baku (limbah ampas sagu) beli Rp 25/kg, artinya bahwa nilai sekarang (present value) dari pendapatan yang diterima bernilai positif selama 12 tahun pada tingkat diskonto sembilan persen. Dengan hasil analisis NPV tersebut ternyata proyek usaha pembuatan pakan ternak dalam mengelola limbah ampas sagu ini dinyatakan layak untuk dilaksanakan.

\begin{tabular}{c|l|r}
\hline No & Indikator Kelayakan & \multicolumn{1}{|c}{ Nilai } \\
\hline 1 & NPV $(\mathrm{Rp})$ & 1.140 .146 .594 \\
\hline 2 & IRR $(\%)$ & 19 \\
\hline 3 & Net B/C & 2,272 \\
\hline 4 & $\begin{array}{l}\text { Payback Period } \\
\text { (tahun) }\end{array}$ & 3,084 \\
\hline
\end{tabular}

Net $B / C$ yang dihasilkan pada tingkat diskonto sembilan persen yaitu sebesar 2,272 dengan asumsi bahan baku (limbah ampas sagu) beli Rp 25/kg. Nilai tersebut menunjukkan bahwa setiap pengeluaran biaya sebesar Rp 1,00 akan menghasilkan manfaat bersih sebesar Rp 2,272 atau dapat disebutkan bahwa pendapatan bersih yang diperoleh adalah sebesar 2,272 kali dari biaya yang dikeluarkan.

Hasil analisis tersebut juga menunjukkan bahwa nilai IRR yang diperoleh yaitu sebesar 19 persen dengan asumsi bahan baku (limbah ampas sagu) beli Rp 25/kg. Nilai ini menunjukkan bahwa investor tidak akan rugi jika dana yang dimiliki digunakan untuk investasi pada proyek usaha pembuatan pakan ternak. Kemampuan proyek untuk mengembalikan modal yang digunakan lebih besar dari discount factor yang digunakan yaitu sebesar sembilan persen. Dengan kata lain 
ditinjau dari kriteria IRR, proyek ini telah memenuhi kriteria kelayakan finansial.

Berdasarkan waktu pengembalian investasinya, digunakan analisis payback period. Dari hasil analisis yang dilakukan, proyek usaha pakan ternak akan mencapai titik pengembalian investasi pada saat proyek telah berumur 3,08 tahun dalam asumsi bahan baku (limbah ampas sagu) beli Rp 25/kg. Hal ini menyatakan bahwa proyek ini dapat mengembalikan modal investasinya sebelum umur proyek berakhir. Dari hasil analisis finansial dengan menggunakan empat kriteria kelayakan dan tingkat diskonto sembilan persen, dapat disimpulkan bahwa proyek instalasi usaha pembuatan pakan ternak ini layak untuk dilaksanakan.

\section{Analisis Skenario}

Analisis sensitivitas pada usaha pakan ternak ini menggunakan 10 skenario dengan empat variabel yang mempengaruhi yaitu penurunan jumlah output (limbah ampas sagu) yang dapat mempengaruhi inflow, serta captive market, kenaikan biaya tetap (tenaga kerja ahli dan tenaga kerja operasional) dan biaya variable (tenaga kerja pelaksana dan packaging). Perubahan yang diamati adalah bagaimana nilai NPV, Net B/C dan IRR jika terjadi perubahan pada jumlah output dengan penurunan 10 persen, penurunan captive market 10 persen, kenaikan biaya tetap (tenaga kerja ahli dan tenaga kerja operasional) dan biaya variabel (tenaga kerja pelaksana dan packaging) masing-masing 20 persen.

Pada saat penurunan jumlah output (ampas sagu) yang mengakibatkan inflow turun yang tidak disertai penurunan captive market, biaya tetap (tenaga kerja ahli dan operasional), biaya variabel (tenaga kerja pelaksana dan packaging) dan penurunan captive market yang tidak dibarengi dengan perubahan ketiga variabel lainnya serta kenaikan biaya tetap (tenaga kerja ahli dan operasional) yang tidak dibarengi dengan perubahan ketiga variabel yang lainnya, dapat dikatakan usaha instalasi pembuatan Pakan Ternak ini masih layak, hal ini disebabkan karena nilai NPV masih bernilai positif, Net B/C rasio lebih besar dari satu dan IRR masih di atas tingkat suku bunga deposito sebesar sembilan persen.

\begin{tabular}{|c|c|c|c|c|c|c|}
\hline \multicolumn{4}{|c|}{ Skenario (\%) } & \multirow[b]{2}{*}{ NPV } & \multirow[b]{2}{*}{ Net B/C } & \multirow[b]{2}{*}{$\begin{array}{l}\text { IRR } \\
\text { (\%) }\end{array}$} \\
\hline $\begin{array}{c}\text { Penurunan } \\
\text { Jumlah } \\
\text { Output } \\
\text { (Ampas } \\
\text { Sagu) }\end{array}$ & $\begin{array}{l}\text { Penurunan } \\
\text { Captive } \\
\text { Market }\end{array}$ & $\begin{array}{c}\text { Biaya } \\
\text { Tetap } \\
\text { (tenaga kerja } \\
\text { ahli } \\
\text { dan tenaga } \\
\text { kerja } \\
\text { operasional } \\
\end{array}$ & $\begin{array}{c}\text { Biaya } \\
\text { Variabel } \\
\text { (tenaga kerja } \\
\text { pelaksa } \\
\text { packaging, } \\
\text { pemasaran }\end{array}$ & & & \\
\hline-10 & 0 & 0 & 0 & 77.476 .904 & 1,864 & 13 \\
\hline 0 & +10 & 0 & 0 & 77.476 .904 & 1,864 & 13 \\
\hline 0 & 0 & +20 & 0 & 113.395 .969 & 2,265 & 19 \\
\hline 0 & 0 & 0 & +20 & 98.310 .383 & 2,097 & 16 \\
\hline 0 & +10 & +20 & 0 & 78.290 .359 & 1,873 & 13 \\
\hline 0 & +10 & +20 & +20 & 61.153 .942 & 1,682 & 11 \\
\hline-10 & 0 & +20 & 0 & 78.290 .362 & 1,873 & 13 \\
\hline 0 & +10 & 0 & +20 & 61.772 .628 & 1,689 & 11 \\
\hline-10 & +10 & +20 & 0 & 44.976 .739 & 1,502 & 8 \\
\hline-10 & +10 & +20 & +20 & 27.840 .322 & 1,310 & 5 \\
\hline
\end{tabular}

Penurunan captive market sebesar 10 persen yang disertai dengan kenaikan biaya tetap (tenaga kerja ahli dan operasional) dan biaya variabel (tenaga kerja pelaksana dan packaging) masingmasing 20 persen, dapat dikatakan juga bahwa usaha ini masih layak karena nilai NPV masih positif, Net $\mathrm{B} / \mathrm{C}$ rasio lebih besar dari satu dan IRR masih di atas tingkat suku bunga. Demikian juga pada penurunan captive market sebesar 10 persen yang dibarengi dengan kenaikan biaya variabel (tenaga kerja pelaksana dan packaging) sebesar 20 persen, usaha ini masih layak karena nilai NPV, IRR dan Net B/C rasio masih diangka yang diharapkan.

Pada saat penurunan jumlah output (ampas sagu) sebesar 10 persen disertai penurunan captive market sebesar 10 persen, kenaikan biaya tetap dan 
biaya variabel masing-masih sebesar 20 persen dapat dikatakan usaha ini tidak layak untuk dilaksanakan, karena nilai IRR di bawah tingkat diskonto yaitu 5 persen.

Dalam kriteria bisnis usaha ini tidak dapat memberikan keuntungan karena nilai IRR di bawah tingkat diskon faktor, lebih baik diinvestasikan kepada proyek lain yang memiliki nilai IRR lebih besar dari diskon faktor.

\section{Switching Value (Nilai Pengganti)}

Analisis switching value digunakan untuk mengetahui tingkat perubahan pada jumlah output (Ampas sagu) untuk mengahasilkan Pakan Ternak dan kompos sebagai inflow, penurunan captive market serta biaya outflow sehingga usaha mendekati keuntungan normal, dimana IRR sama dengan tingkat suku bunga deposito, NPV mendekati nol, dan Net B/C mendekati satu. Pada usaha pendirian Pakan Ternak unggas ini, dari analisis switching value menunjukkan bahwa usaha ini akan menjadi tidak layak jika penurunan jumlah output (ampas sagu) mengalami penurunan sebesar 18,428 persen. Untuk perubahan biaya, usaha ini akan tidak layak jika captive market mengalami penurunan sebesar 12 persen disertai kenaikan biaya tetap (tenaga kerja ahli dan tenaga kerja operasional) sebesar 30 persen dan kenaikan biaya variabel (tenaga kerja pelaksana, packaging) 26,675 persen. Perhitungan analisis switching value menunjukkan usaha pakan ternak ini sangat peka terhadap penurunan jumlah output (ampas sagu).

\section{Analisis Ekonomi Usaha Pakan Ternak}

Analisis ekonomi merupakan analisis usahatani yang melihat dari sudut perekonomian secara keseluruhan. Dalam analisis ekonomi yang diperhatikan ialah hasil total, atau produktivitas atau keuntungan yang didapat dari semua sumber yang dipakai dalam proyek usaha pembuatan pakan ternak untuk masyarakat atau perekonomian sebagai keseluruhan, tanpa melihat siapa yang menyediakan sumber-sumber tersebut dan siapa dalam masyarakat yang menerima hasil proyek tersebut. Hasil itu disebut "the social returns" atau "the economic returns" dari usahatani.

Pada proyek yang feasible (layak) atau memiliki keunggulan komparatif, berarti dari segi efisien proyek tersebut dinilai menguntungkan, dengan kata lain opportunities cost dari sarana produksi yang dipakai oleh proyek lebih rendah daripada opportunities cost sumber-sumber yang perlu digunakan untuk mendapatkan atau menghemat satu dolar. Sebaliknya jika proyek tidak layak atau tidak memiliki keunggulan komparatif, artinya proyek tersebut mengakibatkan pemborosan sumber-sumber nasional karena peluang investasi yang tersedia diluar proyek masih mampu memberikan tingkat keuntungan yang lebih tinggi.

1) Penetapan harga bayangan

a. Lahan

Lahan termasuk dalam input untradable, dimana harga bayangan lahan yang digunakan adalah sama dengan nilai production forgone dari lahan yaitu nilai jual produksi tertinggi dari tanaman lain yang hilang apabila tanah tersebut tidak sedang digunakan sebagai perkebunan aktif. Di Kecamatan Telluwanua tanaman yang ditanam oleh petani responden sebelum digunakan produksi uasaha Pakan Ternak adalah padi dan jagung. Dari kedua 
tanaman tersebut ternyata yang memiliki produksi dengan nilai jual tertinggi adalah jagung yaitu sebesar Rp6.229.000/ha/tahun, oleh karena itu harga bayangan dari lahan adalah sebesar Rp6.229.000/ha/tahun.

b. Nilai tukar mata uang

Harga bayangan nilai tukar rupiah terhadap dolar diperoleh dengan rumus sebagai berikut:

$$
S E R=\frac{O E R}{S C F}
$$

Keterangan:

$$
\begin{aligned}
\mathrm{SER}= & \text { nilai tukar uang bayangan } \\
& (\text { shadow exchange rate }) \\
\mathrm{OER} \mathrm{=} & \text { nilai tukar uang resmi (official } \\
& \text { exchange rate) } \\
\mathrm{SCF}= & \text { factor konversi bahan baku } \\
& (\text { shadow convertion factor })
\end{aligned}
$$

Dimana SCF diperoleh dengan rumus:

$$
S C F=\frac{M+X}{(M+T m)+(X-T x)}
$$

Keterangan:

$$
\begin{aligned}
\mathrm{SCF}= & \text { factor konversi bahan baku } \\
& \text { (shadow convertion factor }) \\
\mathrm{M}= & \text { nilai Impor }(\mathrm{Rp}) \\
\mathrm{Tm}= & \text { pajak Impor }(\mathrm{Rp}) \\
\mathrm{X}= & \text { nilai ekspor }(\mathrm{Rp}) \\
\mathrm{Tx}= & \text { pajak Ekspor }(\mathrm{Rp})
\end{aligned}
$$

Nilai tukar resmi (OER) yang digunakan adalah nilai tukar rata-rata pada tahun 2016 sebesar Rp 12.585/US\$. Pada triwulan I-III tahun 2016, penerimaan negara dari pajak ekspor (Tx) adalah sebesar Rp36.024.010, sedangkan bea masuk impor (Tm) adalah sebesar Rp30.942.040. Adapun nilai ekspor Indonesia (X) triwulan I-III tahun 2016 adalah Rp710.191.700, sedangkan nilai impor (M)
Indonesia adalah sebesar Rp637.088.300.000 (BPS Sulawesi Selatan, 2016). Berdasarkan nilai- nilai tersebut maka diperoleh faktor konversi bahan baku (SCF) tahun 2016 adalah sebesar 1,037, sehingga harga bayangan nilai tukar mata uang yang diperoleh adalah sebesar Rp12.549,63/US\$.

c. Ampas Sagu "entrys"

Harga bayangan bahan baku yang digunakan adalah sama dengan harga privatnya. Begitu pula dengan harga bayangan batang "entrys" yang digunakan adalah harga privatnya. Hal ini disebabkan "entrys" merupakan barang yang tidak diperdagangkan (untradable input).

d. Variabel pendukung (Ragi)

Ragi yang digunakan dalam fermentasi limbah ampas sagu adalah ragi kue yang ada di pasaran. Maka harga bayangan dihitung dengan menggunakan harga CIF. Sedangkan harga bayangan ragi yang digunakan adalah sama dengan harga privatnya.

e. Tenaga kerja

Harga bayangan tenaga kerja ditentukan berdasarkan jumlah dari production foregone (nilai yang seharusnya diterima seorang tenaga kerja yang bersangkutan bila ia tidak bekerja di usaha pembuatan pupuk), biaya pengangkutan tenaga kerja tersebut dari daerah tempat tinggalnya ke lokasi proyek, dan biaya makan dan pakaian.

Tenaga kerja yang digunakan dalam penelitian ini berasal dari masyarakat daerah setempat yang mengangur bila tidak ada usaha pembuatan pupuk, sehingga diasumsikan bahwa nilai productionforegone sama dengan 
nol, selain itu karena berasal dari masyarakat setempat maka diasumsikan tidak ada biaya pengangkutan tenaga kerja. Sehingga harga bayangan upah tenaga kerja atau shadow wage adalah sama dengan nilai upah tenaga kerja finansial atau sebesar $0 \%$ dari nilai upah finansialnya yaitu sebesar Rp 25.000/jam untuk semua tenaga kerja.

f. Bangunan dan alat-alat produksi

Alat produksi yang digunakan dalam usaha pembuatan pakan ternak yang bersifat tradable adalah sprayer. Sprayer tersebut merupakan barang impor dengan menggunakan harga CIF.

Harga bayangan untuk bangunan dan alatalat usaha pembuatan pakan selain sprayer yang digunakan dalam pembuatan pakan ternak adalah sama dengan harga privatnya karena bangunan dan alat-alat pertanian tersebut termasuk barang yang tidak diperdagangkan (untradable inputs).

g. Output

Output dalam penelitian ini adalah Pakan ternak unggas dalam bentuk kering (pellet) dengan rendemen 20\%, selain itu petani di Kecamatan Telluwanua juga mengusahakan tanaman tumpang sari (lada dan kakao) di selasela area produksi usaha pakan ternak mereka, dimana hasil penjualan produksinya dapat menambah penerimaan.

Harga bayangan pakan ternak (pellet), lada, dan kakao diperoleh dari harga batas (border price).

h. Bunga modal

Harga bayangan bunga modal adalah tingkat suku bunga tabungan privat tahun 2016 yaitu sebesar $11,80 \%$ ditambah dengan ratarata tingkat inflasi bulanan selama 2 tahun (2015-2016) yaitu sebesar 12,69\% (www.bi.go.id, diakses tanggal 26 Januari 2016). Berdasarkan perhitungan tersebut diperoleh harga bayangan bunga modal sebesar $24,49 \%$.

\begin{tabular}{c}
\hline SIMPULAN \\
\hline Analisis pada aspek-aspek penunjang
\end{tabular}
kelayakan usaha yaitu aspek teknis, aspek pasar, aspek manajemen dan aspek sosial menunjukkan bahwa pendirian usaha pakan ternak layak untuk dilaksanakan.

Pada aspek teknis pengadaan input pada mesin dan peralatan biaya investasi masih sangat tinggi. Berdasarkan aspek manajemen, manajemen pembuatan usaha pakan ternak ini sangat sederhana karena usaha ini baru akan didirikan. Untuk aspek pasar, potensi yang cukup besar terhadap peluang pasar pakan ternak di wilayah Luwu Raya dan Sekitarnya. Hasil analisis kelayakan finansial Pembuatan Usaha Pakan Ternak dengan potensi limbah 5000 Ton dan menghasilkan pakan ternak sebesar $2.100 \mathrm{~kg}$ per tahun, dengan tingkat diskonto sembilan persen nilai NPV sebesar Rp. 114.014.659,48 dengan asumsi bahan baku (limbah ampas sagu) beli $\mathrm{Rp}$ 25/kg atau lebih besar dari nol, nilai Net B/C adalah sebesar 2,272 atau lebih dari 1. Nilai IRR yang diperoleh adalah sebesar 19 persen atau lebih besar dari tingkat diskonto yang ditentukan. Nilai Payback Period adalah tiga tahun. Berdasarkan hasil analisis kelayakan finansial maka usaha pembuatan pakan ternak berbahan dasar limbah ampas sagu layak untuk dilaksanakan. 
Hasil analisis sensitivitas dengan skenario menunjukkan bahwa pada usaha pembuatan pakan ternak ini akan tidak layak dilaksanakan pada kondisi jika terjadi penurunan jumlah output (limbah apas sagu) sebesar 10 persen disertai dengan penurunan captive market sebesar 10 persen, biaya tetap (tenaga kerja ahli dan operasional) sebesar 20 persen. Sedangkan pada kondisi penurunan captive market sebesar 10 persen disertai kenaikan biaya variabel dan kenaikan biaya tetap menunjukkan usaha masih layak dilaksanakan.

Analisis Switching Value menunjukkan usaha ini akan tidak layak pada penurunan potensi limbah ampas sagu lebih dari 18,428 persen dan penurunan captive market sebesar 12 persen disertai kenaikan biaya tetap (tenaga kerja ahli dan operasional) yang dapat ditoleris adalah sebesar 30 persen dan kenaikan biaya variabel (tenaga kerja pelaksana, packaging) sebesar 26,675 persen. Dapat dikatakan usaha pembuatan pakan ternak ini sangat peka terhadap penurunan jumlah output (ampas sagu) dan captive market yang mempengaruhi inflow.

Usaha pembuatan Pakan Ternak Unggas di Kelurahan Pentojangan Kecamatan Telluwanua, Palopo layak dilaksanakan pada kondisi modal yang dipakai adalah sepenuhnya modal sendiri. Usaha ini bagi bukan hanya sebagai core bussines, tapi juga sebagai upaya untuk menangani limbah perkebunan dan sebagai tanggung jawab Perguruan Tinggi terhadap lingkungan dan masyarakat sekitar.

\section{DAFTAR PUSTAKA}

Flach, M., 1977. 'Yield Potential of the Sago Palm, Metroxylon sagu, and its Realization.' In K.
Tan (ed.) Sago-76: Papers of the First International Sago Symposium. Kuala Lumpur: Kamajuan Kanji.

Flach, M., 1997. Sago palm. Metroxylon sagu Rottb. Promoting the conservation and use of underutilized and neglected crops. Rome: International Plant Genetic Resources Institute.

Ginting, G.S, 1991. Keterpaduan Ternak Ruminansia dengan Perkebunan, Produksi dan Nilai Nutrisi. Jurnal Penelitian dan Pengembangan Pertanian. Departemen Pertanian.

Gittinger, James Price. 1986. Analisa ekonomi Proyek-proyek Pertanian, Universitas Indonesia Press. Jakarta.

Gray, Clive dan Payaman Simanjutak, Lien K. Sabur, P.F.L. Maspaitella, R.C.G. Varley. 2002. Pengantar Evolusi Proyek. PT. Gramedia Pustaka Utama. Jakarta.

Khan, M.A., M. Sarwar and M.M.S. Khan. 2004. Feeding value of urea treated corncobs ensiled with or without enzose (corn dextrose) for lactating crossbred cows. Asian-Australia Journal Animimal Science. 8: 1093 - 1097.

Kiston Simanihuruk, A. Chaniago dan J. Sirait. Silase ampas sagu sebagai pakan dasar pada Kambing kacang sedang tumbuh. Seminar Nasional Teknologi Peternakan dan Veteriner 2011. Prosiding.

Kompiang, I.P. 1995. Kumpulan Hasil Penelitian Ternak Unggas dan Aneka Ternak. Balai Penelitian Ternak, Ciawi.

Mirnawati dan G. Ciptaan. 1999. Pemakaian empulur sagu (metroxilon sp) fermentasi dalam ransum terhadap retensi nitrogen dan rasio efisiensi protein pada ayam Broiler. Jurnal Ilmu Peternakan dan Lingkungan. 5(01): 8-12.

Nurdin. M. 1995. Pemanfaatan Ampas Sagu Sebagai Subtrat Pembuatan Protein Sel Tunggal. Laporan Hasil Penelitian, Lembaga Penelitian Unhalu. Kendari. 
NRC. 1981. Nutrient Requirement of Goats: Angora, Dairy, and Meat Goats in Temperate and Tropical Countries. National Academy Pr., Washington DC.

Nurkurnia, E. 1989. Hasil Fermentasi Rumen Kambing Kacang Betina dengan Pemberian Beberapa Tingkat Ampas Sagu (Metroxylon sp.) dalam Ransum. Skripsi. Fakultas Peternakan Institut Pertanian Bogor, Bogor.

Prastowo, B. 2007. Potensi sektor pertanian sebagai penghasil dan pengguna energy terbarukan. Perspektif 6(2): 84 - 92.

Ruddle, K. E. A., 1978. Palm Sago: A Tropical Starch from Marginal Lands. Honolulu: University of Hawaii Press.

Rumalatu. F.J. 1981. Distribusi dan potensi pati beberapa sagu (Metroxylon sp.) di daerah Seram Barat. Karya Ilmiah. Fakultas Pertanian/Kehutanan yang berafiliasi dengan Fateta IPB, Bogor.

Sapieza, D.A. dan K.K. Bolsen. 1993. Teknologi Silase (Penanaman, Pembuatan dan Pemberiannya pada Ternak). Penerjemah: Martoyondo Rini B.S.

Sembiring, Andri, 2002. Analisis Kelayakan Finansial dan Ekonomi Proyek Land Application. Skripsi Jurusan Ilmu Sosial Ekonomi Pertanian. Institut Pertanian Bogor.

Townsend, P. K., 1977. 'The Cultural Ecology of Sago in New Guinea.' In K. Tan (ed.) Sago76: Papers of the First International Sago Symposium, pp. 91-95.

Trisnowati, 1991. Kecernaan in vitro Ampas Sagu Metroxylon yang Diperlakukan Secara Biologis. Skripsi. Fakultas Peternakan Institut Pertanian Bogor, Bogor.

Uhi, H.T., Usman, S. Tirajoh, dan B. Tiro. 1997. Pengkajian pemanfaatan pakan ternak potensial di Irian Jaya. Laporan Hasil Pengkajian LPTP Koya Barat, Jayapura.

Harry Tum dan Batsebat Wiro (1999). Pemanfaatan Ampas Sagu (Metroxylon
Sagu) Sebagai Pakan Ayam. Seminar Nasional dan Veteriner.

Vyas, V. S, "Some Aspect of Struktural Change in Indian Agriculture," Indian J. Agri. Economics., vol. XXXIV, No. JanuariMaret 1979. 